\title{
Potential Benefits of the Self-Administration of Subcutaneous Methotrexate with Autoinjector Devices for Patients: A Review
}

This article was published in the following Dove Press journal:

Drug, Healthcare and Patient Safety

\author{
Jesús Tornero Molina' \\ Juan Carlos López Robledillo ${ }^{2}$ \\ Núria Casamira Ruiz $\mathbb{D}^{3}$ \\ 'Department of Rheumatology, Hospital \\ de Guadalajara, Guadalajara, Spain; \\ ${ }^{2}$ Department of Rheumatology, Hospital \\ del Niño Jesús, Madrid, Spain; ${ }^{3}$ Medical \\ Department, Gebro Pharma S.A, \\ Barcelona, Spain
}

\begin{abstract}
The role of patient adherence in improving the efficacy of any treatment is widely accepted, as well as its impact in optimizing the use of healthcare resources and associated costs. Adherence is particularly affected in chronic conditions, such as rheumatoid arthritis (RA), requiring long-term therapies and a commitment of the patient to manage his/her disease. Methotrexate (MTX) is one of the mainstays of treatment for several immunemediated inflammatory joint and skin diseases, especially RA. The use of parenteral MTX, particularly when administered as a subcutaneous (SC) injection, has recently raised a great interest to overcome the limitations of oral MTX. For addressing this issue, new optimized self-injection systems have been developed to improve the ease of use of SC MTX. Increasing evidence shows how patients tend to opt for autoinjectors over prefilled syringes or conventional syringes in terms of easiness of use, preference and satisfaction, regardless of whether the treatment is a biologic or MTX. Additionally, positive views and beliefs of patients about treatment may contribute to increasing expectations of effectiveness and treatment adherence. Similarly, the implementation of prefilled pens in clinical practice might be a way to facilitate and simplify the self-injection of SC MTX delivery, optimizing adherence and treatment outcomes as a consequence. This article aimed to review the available literature data on the use of MTX autoinjectors and their impact on treatment adherence and patients' perceptions.
\end{abstract}

Keywords: adherence, rheumatoid arthritis, methotrexate, autoinjector

\section{Introduction}

Therapeutic efficacy depends on the quality of a drug, its bioavailability and medication adherence. Medication nonadherence for chronic conditions remains a challenge to contemporary medicine. The World Health Organization (WHO) claimed in 2003 that improving patient adherence to long-term therapies would be as beneficial as any biomedical progress. Consequently, patients' adherence to treatment has become a major requirement for improving chronic disease control and optimizing the use of healthcare resources and costs. ${ }^{1-4}$ Rheumatoid arthritis (RA) is a chronic systemic autoimmune inflammatory disease with a prevalence of around $1 \%$ in developed countries. ${ }^{5,6}$ The inadequate control of the RA may lead to accumulating joint damage, irreversible disability, poorer quality of life (QoL) and higher mortality. ${ }^{7,8}$ Therefore, efforts addressed to gain knowledge of the factors causing poor adherence will lead to better outcomes. Reasons for poor adherence may be related to disease, treatment, provider, the health system and the patient.
Correspondence: Núria Casamira Ruiz Medical Department, Gebro Pharma S.A, Avenida del Tibidabo, 29, Barcelona, 08022, Spain

Tel +34932058686

Fax +34932058684

Email nuria.casamira@gebro.es
Drug, Healthcare and Patient Safety 202I:13 8I-94

mit your manuscript

DovePres: in $\square$ 
Patients' needs are specific to their situation, hence the need to better understand the relationship between patients' perceptions of the need for a given treatment if we want to improve medication adherence. In short, a therapy framework should meet patient circumstances for optimal efficacy and more effective use of healthcare resources. ${ }^{1-4,9-11}$ Treatment adherence in RA has been extensively investigated and reviewed in several metaanalyses $^{12-15}$ that show suboptimal compliance, especially to the reference therapy methotrexate (MTX). The subcutaneous (SC) formulation of MTX, unlike the oral delivery, is the best option in pursuing a higher efficacy and better tolerability; but while the route of administration does not appear to influence drug adherence in RA, ${ }^{14,16-22}$ some difficulties associated with syringe use may difficult the use of the SC delivery. Therefore, to avoid the problems in administering self-injections using the classic syringes from reduced manual dexterity patients with RA, new drug-delivery devices have been developed that facilitate the use and reduce the discomfort. Although the evidence is not robust, optimizing the SC self-administration of MTX could have the potential to improve adherence.

This narrative review is based on the following premises: 1) patient's perceptions about medication play an important role in adherence and, in consequence, in clinical outcomes and medical costs of chronic diseases such as RA; 2) the SC MTX has gained attention among rheumatologists during the last years, and devices for self-injection have increased as an alternative to classic syringes; 3) these new marketed devices have shown a high level of usability, acceptance, and satisfaction that may lead to enhance the clinical outcomes. Thus, we aim to discuss the role of the autoinjector devices in adherence and whether their implementation in clinical practice improves therapy outcomes.

\section{Materials and Methods}

We conducted a narrative review of the literature using the following methodology. The literature search strategy was focused on the following question using the PICO framework: ${ }^{23}$

"How does the use of pens/autoinjectors versus others forms of injection affect medication adherence and perceptions of patients with RA receiving long-term therapies?. (where the "Participants" are the "patients with RA" and those receiving "long-term therapies," the "Intervention" is "the use of pens/autoinjectors," the "Comparator" is "other forms of injection?" and the "Outcome" is "medication adherence and patient perceptions")".

Citations were limited to those from indexed journals, communications from international meetings, and government entity guidelines (eg, WHO). Studies also had to be published in English within the last 15 years. Any article outside of our focus of interest, ie, any publication that did not answer the question we were asking was excluded.

Literature search was conducted through the PubMed and Google Scholar databases, using combined Medical Subject Headings (MeSH) and free-text terms related to "methotrexate", "rheumatoid arthritis", "chronic disease", "long-term treatment/therapy", "lifespan treatment/adherence", "diseasemodifying antirheumatic drugs (DMARDs)" "adherence", "compliance", "persistence", "preference", "ease of use", "satisfaction", "pen”, “auto-injector", "prefilled”, "syringe”.

We perform two rounds of searching (Figure 1). In the first round, we extracted 84 citations, from which 13 were discarded after reviewing the title and abstract and confirming that the topic was not related to the purpose of this review. In the second round, 13 citations were excluded for not fulfilling the inclusion criteria. Finally, we selected 58 citations that responded more accurately to our question. Furthermore, studies were ranked by scientific evidence level. Thus, preference was given to systematic reviews and meta-analysis over narrative reviews and to guidelines from government entities over authors' opinions; in the latter case, the opinion of committees was preferred over a single author's opinion.

\section{Results \\ Overview of Patient Medication Adherence Concept and Measures}

Adherence is defined as "the extent to which a patient acts per the prescribed interval and dose of a dosing regimen". ${ }^{24}$ Adherence is usually reported as the percentage of the prescribed doses of medication taken by the patient over a specific period, although in retrospective studies, the concept of medication possession ratio (MPR) is often employed. ${ }^{24}$ The term compliance, sometimes wrongly referred to as adherence, implies patient obedience in following the prescriber's recommendations. A type of non-adherence is called non-persistence, which describes the percentage of patients who decide not to continue taking the medication without medical advice.

In short, the concept and measure of adherence are as complex and variable as factors affecting it which range from patient expectations and attitudes, and disease characteristics, 
Selection of 84 citations identified in Pubmed + Google Scholar

13 excluded after reviewing title \& abstract

71 selected by specific criteria

13 excluded for not meeting inclusion

criteria:

- Old data

and/or

- Not indexed journal

and/or

- Not international meeting

communication

and/or

- Not guideline of government entity

and/or

- Not available in English

58 citations selected for narrative review

Figure I Literature search workflow diagram. From the initially identified citations, they were finally selected 58 meeting the inclusion criteria and responded to the following question using the PICO framework: "How does the use of pens/autoinjectors versus other forms of injection affect medication adherence and perceptions of patients with RA receiving long-term therapies".

to convenience, cost, route of administration, adverse events, and practitioner support. ${ }^{25}$ If focused on RA several studies have also shown different estimates of MTX adherence because of the heterogeneity in the assessment methods. ${ }^{12}$ For instance, MPR, the Compliance Questionnaire Rheumatology (CQR), the Visual Analogue Scale (VAS), the Medication Event Monitoring System (MEMS), drug record registry, claims data, and the Medication Adherence Report Scale (MARS-5) ${ }^{12,13,15}$ have been used throwing a variety of results that do not allow to build a clear pattern of factors that influence adherence and persistence.

\section{Methotrexate in Rheumatoid Arthritis Management: The Importance of Subcutaneous Administration and the Influence of the Route of Administration} MTX is a mainstay in the therapy of RA. ${ }^{26,27}$ However, evidence indicates high variability in terms of efficacy and safety outcomes that can be ascribed, at least in part, to the individual's pharmacogenomic profile. The saturable intestinal absorption of oral MTX limits its bioavailability and efficacy ${ }^{26}$ while SC administration results in rapid and complete absorption, higher serum levels, and less variable exposure. In some cases, the use of parenteral route should be considered to overcome the limitations of oral administration of MTX. A recent article by Tornero Molina et $a l,{ }^{16}$ for the use of parenteral MTX in rheumatic diseases, mainly RA, and based on best evidence and experience in order to solve frequent questions and help in decision-making strategies, indicated that patients with an inadequate response to oral MTX (15 mg/week), escalating the dose utilizing the parenteral route is clinically more effective. The use of parenteral MTX is recommended to be also considered in patients with highly active disease, poor adherence to oral treatment, taking multiple drugs, or obesity. ${ }^{16}$

Additionally, considering the expert consensus document by Tornero-Molina et al, in RA patient's refractory or intolerant to oral MTX and even poor-adherents, the switch to SC MTX is recommended before introducing a biologic agent. ${ }^{17}$ The assessment of effectiveness and safety of SC MTX has been mainly focused on RA and evidence highlights the superior clinical efficacy of SC MTX over oral MTX. ${ }^{26}$ Moreover, the higher drug exposure resulting from SC administration does not entail 
a higher risk of gastrointestinal adverse events or increased safety issues.

A multicenter, randomized, double-blind trial comparing the efficacy and safety of oral and SC MTX in patients with active RA found that $\mathrm{SC}$ administration was significantly more effective than oral administration with no differences in tolerability. ${ }^{20}$ This fact has also been described in a prospective study even without an increase in adverse effects. ${ }^{28}$ Another study in a prospective cohort of patients with early RA concluded that initial SC MTX was associated with lower rates of treatment failures and greater clinical efficacy than oral MTX, with no difference in toxicity taking into account the expected difference in MTX bioavailability when SC MTX is administered compared to oral MTX at higher doses. ${ }^{26}$ A short-term study demonstrated that oral split doses of MTX are better than an oral single dose and similar to parenteral MTX in terms of efficacy. ${ }^{29}$ However, MTX given orally shows a lower absorption and a worse safety profile regarding gastrointestinal toxicity that may justify the switch to SC MTX instead to biologics. ${ }^{16-20,22,27}$

Likewise, as we have previously mentioned, based on the expert consensus document by Tornero-Molina et al., and should being re-evaluated periodically, in situations where initial doses are necessary as in overweight patients, the switch from oral MTX to SC MTX is also recommended. ${ }^{17}$ In support of this, evidence has demonstrated that SC MTX both as initial therapy in naive patients ${ }^{20,26}$ or subsequent therapy in non-responder patients improves treatment persistence, and clinical efficacy mainly due to its favorable bioavailability, $^{30}$ and optimizes the use of healthcare resources. $^{27}$ Notably, a recent subanalysis of the RA Excellence project in Spain showed that MTX escalation to full doses is not done with adequate speed and that the subcutaneous route is used in a small proportion of patients in clinical practice (only $12 \%$ of patients changed the route of administration). ${ }^{31}$ Similarly, the study Symphony Health Solutions covering 274 million patients in the US showed that only $16 \%$ of patients were changed from oral to SC MTX. ${ }^{18}$ That is, realworld evidence is highlighting the underuse of SC MTX after failure to oral administration, despite the recommendation that RA patients need to have tried and failed both oral and SC MTX before assuming a complete failure or intolerance to MTX and start biologics administration. This recommendation has been adopted considering the evidence that $\mathrm{SC}$ administration ensures higher plasma concentration and drug bioavailability, and thus greater clinical efficacy. ${ }^{19,20,32}$ There is even evidence that the use of SC MTX after oral delays the onset of biological therapy. The MENTOR study, for example, provided evidence for the effectiveness and enhanced tolerability of SC MTX in prolonging disease control in patients who have failed oral MTX without necessarily the need to introduce alternative DMARD or biologic therapy. ${ }^{33}$ Several studies have proposed that SC MTX has an important role to play in the long-term management of patients with RA from higher-cost treatment pathways to lower-cost treatment pathways. It can be also self-administered at home, providing an improvement in patient satisfaction. ${ }^{34,35}$ Taylor et al., provided an evidence-based discussion as to how to achieve the best outcomes with MTX in the management of RA highlighting that the parenteral administration of MTX has the advantages of maximising bioavailability, reducing gastrointestinal intolerance, and potentially enhancing compliance and adherence being highly cost-effective. ${ }^{36}$ Based on the 2016 European League Against Rheumatism (EULAR) recommendations from 2016, MTX should be part of the first treatment strategy with csDMARDs, except in patients with contraindication and in case of nonresponse, change to another csDMARD as a strategy before adding a biological. ${ }^{21}$

MTX remains the initial drug of choice for treating RA, both as monotherapy and in combination with other RA drugs, ${ }^{21}$ and the SC route is the best alternative to achieve better clinical outcomes; however, the evidence available about the effect of using the SC formulation to improve adherence is not so conclusive. While several studies demonstrated improved treatment continuation associated with SC MTX over the first year of treatment compared to oral administration, ${ }^{26}$ others found improved persistence either in patients initially treated with SC MTX or those switched from oral to $\mathrm{SC}$ administration ${ }^{30}$ similar adherence regardless of the route of administration, ${ }^{14}$ or MTX adherence highly variable because of different populations, follow-up durations, adherence definitions or assessment methods. ${ }^{12}$ Added to this is the difficulty that many patients may have in self-medicating, or the pain, anxiety, discomfort, and syringe fear they may experience, which, although do not contribute directly to increase adherence, is affecting the convenience of treatment and patient motivation. 


\section{Pen Devices and Autoinjectors for Drug Parenteral Administration}

The long-term goal of RA medications is to slow or stop the disease process, particularly joint damage, so patients can preserve their autonomy and QoL. Optimizing forms of administration is likely to facilitate the treatment compliance and commitment that chronic treatments require.

For some patients, RA therapies need to be injected. However, they may have difficulties in manipulating syringes as a result of the functional impairment of the disease and the hand small joint involvement impairing dexterity.

Additionally, evidence supports that many patients with RA show difficulty in adhering to their medication, and that patient preferences and motivations positively affect adherence since it facilitates the acceptance of the issues surrounding medication for chronic disease. ${ }^{1-4,11}$ A recent systematic of patients' perspectives on the $\mathrm{SC}$ route of administration ${ }^{22}$ demonstrates the importance of the distinct methods and routes of administration on patient choice for the management of chronic disorders (diabetes, growth hormone deficiency, migraine, multiple sclerosis, and RA). These studies concluded that pen devices and autoinjectors are preferred to deliveries via needle or syringes in terms of convenience and portability. ${ }^{22}$ Table 1 presents the publications reviewed which deal with the use of self-injection devices for different chronic conditions and long-term therapies. Adherence to diabetic medication has been widely studied together with patient preferences and other perceptions. ${ }^{37-39}$ These studies found better outcomes with pen usage and a positive effect of the utilization of such devices. Furthermore, a narrative $e^{25}$ and systematic review ${ }^{40}$ compiled information on adherence/perceptions from type 2 diabetes mellitus (DM2) patients using pen devices for insulin administration. Conclusions advocated simplifying treatment regimens and caring patient motivation and education among the interventions to optimize adherence ${ }^{25}$ which positively correlates with the use of pen devices. ${ }^{40}$ In patients with inflammatory bowel disease, compliance with biologic therapy is favorable with more than three-quarters of patients who adhere to their anti-TNF therapy. ${ }^{41}$ For instance, a study in patients with ulcerative colitis showed that the majority preferred self-administration with golimumab autoinjector over a prefilled syringe. ${ }^{42}$ In multiple sclerosis, the adherence to medication has been focused on interferon beta-1a SC devices. The ATTAIN and REDEFINE studies reported a preference for once-weekly autoinjectors over prefilled syringed among patients. ${ }^{43}$
It would be hypothesized that the characteristics of the disease may impact perceptions of devices. To address this hypothesis, a study to assess the performance, safety, subject acceptance and compliance of a disposable autoinjector for $\mathrm{SC}$ injections of MTX in healthy volunteers was performed, comparing SC injections performed by subjects using the autoinjector with $\mathrm{SC}$ injections performed by nurses using a syringe. ${ }^{44}$ No differences were found in terms of safety or performance between the two delivery ways but better outcomes were obtained in terms of pain, preference, and acceptance when the drug was self-administered. ${ }^{44}$

Several studies have demonstrated that self-injection versus injection by health care workers can increase patient treatment adherence and, consequently, reduce costs by decreasing the frequency of hospital visits, which benefits patients in terms of cost, time, ease of use, improved self-esteem, and greater independence in their social, domestic, and professional lives. ${ }^{45,46}$

RA is a good example of how the limitations related to the severity of disease and progression may affect medication adherence by complicating the procedure of self-autoinjection. A study in RA patients ${ }^{47}$ showed a high level of patient acceptance of an autoinjector developed for facilitating the SC self-injection, which had been successfully tested in healthy volunteers ${ }^{44}$ and patients with multiple sclerosis. ${ }^{48}$ Notably, usability and compliance were successful in patients with severe hand disability. ${ }^{47}$ The findings of this study add to the evidence supporting the use of autoinjectors to help improve treatment compliance among patients with chronic diseases.

Results from several studies have shown that patients with RA favor treatment devices that are easy to use, convenient, less painful and take less time to use, and patients have demonstrated a preference for autoinjector devices over more conventional methods of treatment administration, ${ }^{48-53}$ such as syringes.

The TOUCH study, ${ }^{49}$ which evaluated two self-administration devices for adalimumab, a prefilled syringe and an autoinjection pen, showed how patients preferred the pen versus the syringe and perceived it as easier to use and more convenient. Furthermore, a considerable proportion of patients reported that the pen was less painful to use than the syringe.

Two etanercept autoinjectors, when compared, showed different ratings of preference and acceptability that varied in function of specific attributes of the devices. ${ }^{50}$ The abatacept pre-filled autoinjector has demonstrated to be highly acceptable. $^{51}$ Patient satisfaction and confidence regarding 
Table I Parenteral Self-Administration Through Pen/Autoinjectors for Long-Term Therapies and Chronic Diseases

\begin{tabular}{|c|c|c|c|}
\hline $\begin{array}{l}\text { Drug Delivered } \\
\text { and Condition }\end{array}$ & Reference & $\begin{array}{l}\text { Type of } \\
\text { Publication }\end{array}$ & Summary \\
\hline \multirow{16}{*}{$\begin{array}{l}\text { - Insulin } \\
\text { - Diabetes }\end{array}$} & \multirow{4}{*}{$\begin{array}{l}\text { Cheen et al, } \\
2014^{37}\end{array}$} & \multirow{4}{*}{$\begin{array}{l}\text { Research } \\
\text { article }\end{array}$} & - Retrospective observational study, single center, $\mathrm{N}=955$ patients. \\
\hline & & & - Outcome measure adherence in terms of: compliance (by MPR) \& persistence. \\
\hline & & & - Comparison of patients using prefilled pens vs those using vial/syringe. \\
\hline & & & - Results: despite MPR was similar, prefilled pen users were more persistent. \\
\hline & \multirow{4}{*}{$\begin{array}{l}\text { Ramadan et al, } \\
2015^{39}\end{array}$} & \multirow{4}{*}{$\begin{array}{l}\text { Research } \\
\text { article }\end{array}$} & - Prospective observational study, 5 centers, $\mathrm{N}=7 \mathrm{I}$ patients. \\
\hline & & & $\begin{array}{l}\text { - Primary endpoints: simplicity \& safety of administration, preference \& convenience of } \\
\text { patients. }\end{array}$ \\
\hline & & & - Comparison of patients using pens vs those using conventional vial/syringe. \\
\hline & & & - Pen was easier to use and less painful. \\
\hline & \multirow[t]{4}{*}{$\begin{array}{l}\text { Miao et al, } \\
2014^{38}\end{array}$} & \multirow[t]{4}{*}{$\begin{array}{l}\text { Research } \\
\text { article }\end{array}$} & $\begin{array}{l}\text { - Retrospective observational study, database, } N=7856 \text { patients of } D M 2 \geq 65 \text { years old, insulin } \\
\text { glargine. }\end{array}$ \\
\hline & & & - Follow-up study outcomes: persistence and adherence (by MPR). \\
\hline & & & - Comparison of patients using disposable pens vs those using conventional vial/syringe. \\
\hline & & & - Results: Pen users showed greater persistence, duration of persistence and adherence. \\
\hline & \multirow[t]{2}{*}{$\begin{array}{l}\text { Tiktin et al, } \\
2016^{25}\end{array}$} & \multirow[t]{2}{*}{$\begin{array}{l}\text { Narrative } \\
\text { review }\end{array}$} & $\begin{array}{l}\text { - Literature search aiming to identify factors affecting adherence to medications in DM2, N= } 30 \\
\text { studies. }\end{array}$ \\
\hline & & & $\begin{array}{l}\text { - Authors recommend to simplify regimes, to improve provider-patient communication } \\
\text { and to provide support and education of patients. }\end{array}$ \\
\hline & \multirow[t]{2}{*}{$\begin{array}{l}\text { Lasalvia et al, } \\
2016^{40}\end{array}$} & \multirow{2}{*}{$\begin{array}{l}\text { Systematic } \\
\text { review/ } \\
\text { meta- } \\
\text { analysis }\end{array}$} & $\begin{array}{l}\text { - Revision to evaluate efficacy of pens vs vial/syringe, finally included } N=17 \text { studies on } \\
\text { DM2. }\end{array}$ \\
\hline & & & $\begin{array}{l}\text { - Authors concluded that pen use yields clinical benefits and is positively correlated to } \\
\text { patient adherence/preference. }\end{array}$ \\
\hline \multirow{8}{*}{$\begin{array}{l}\text { - Biologics anti- } \\
\text { TNF } \\
\text { - Autoimmune \& } \\
\text { chronic } \\
\text { inflammatory } \\
\text { diseases }\end{array}$} & \multirow[t]{2}{*}{$\begin{array}{l}\text { Lopez et al, } \\
2013^{41}\end{array}$} & \multirow[t]{2}{*}{$\begin{array}{l}\text { Systematic } \\
\text { review }\end{array}$} & $\begin{array}{l}\text { - Revision of methods of assessment, prevalence and predictors of non-adherence in } \\
\text { inflammatory bowel diseases, finally included } N=13 \text { studies }\end{array}$ \\
\hline & & & $\begin{array}{l}\text { - Authors concluded }>75 \% \text { adhere to biologics and suggests that syringe vs pen might be } \\
\text { a predictor for non-adherence. }\end{array}$ \\
\hline & \multirow{2}{*}{$\begin{array}{l}\text { Kivitz \& } \\
\text { Segurado } \\
2007^{70}\end{array}$} & \multirow[t]{2}{*}{$\begin{array}{l}\text { Expert } \\
\text { opinion }\end{array}$} & $\begin{array}{l}\text { - Authors focus on adalimumab-charged HUMIRA pen (adalimumab) and the outcomes } \\
\text { of the TOUCH study. }\end{array}$ \\
\hline & & & - Authors suggests pens/autoinjectors would become the preferred choice. \\
\hline & \multirow[t]{4}{*}{$\begin{array}{l}\text { Vermeire et al, } \\
2018^{42}\end{array}$} & \multirow[t]{4}{*}{$\begin{array}{l}\text { Research } \\
\text { article }\end{array}$} & $\begin{array}{l}\text { - Open-label, multicenter, randomized crossover clinical trial, } \mathrm{N}=91 \text { moderate-to- } \\
\text { severe ulcerative colitis patients. }\end{array}$ \\
\hline & & & $\begin{array}{l}\text { - Assessments: preference, self-injection perceptions (ease-of-use, discomfort, overall } \\
\text { impression), safety. }\end{array}$ \\
\hline & & & - Comparison of golimumab prefilled syringe vs autoinjector. \\
\hline & & & - Authors concluded patients generally prefer autoinjectors. \\
\hline
\end{tabular}

(Continued) 
Table I (Continued).

\begin{tabular}{|c|c|c|c|}
\hline $\begin{array}{l}\text { Drug Delivered } \\
\text { and Condition }\end{array}$ & Reference & $\begin{array}{l}\text { Type of } \\
\text { Publication }\end{array}$ & Summary \\
\hline \multirow[t]{12}{*}{$\begin{array}{l}\text { - IFN- } \beta \text { Ia } \\
\text { - Multiple } \\
\text { sclerosis }\end{array}$} & \multirow[t]{5}{*}{$\begin{array}{l}\text { Seddighzadeh } \\
\text { et al, } 2014^{71}\end{array}$} & \multirow[t]{5}{*}{$\begin{array}{l}\text { Research } \\
\text { article }\end{array}$} & $\begin{array}{l}\text { - Sub-study: data mining from the ATTAIN trial (extension of the ADVANCE trial: Phase } \\
\text { III, double-blind, randomized, multi-center), } N=39 \text { relapsing-remitting multiple sclerosis } \\
\text { patients. }\end{array}$ \\
\hline & & & $\begin{array}{l}\text { - Assessments: safety, tolerability (pain by patient \& clinician), patient perceptions (ease- } \\
\text { of-use, satisfaction). }\end{array}$ \\
\hline & & & - Comparison of peginterferon-betala prefilled syringe vs autoinjector. \\
\hline & & & $\begin{array}{l}\text { - Results: similar safety \& tolerability profile, patient find autoinjector easy to use and } \\
\text { convenient. }\end{array}$ \\
\hline & & & - Authors suggests autoinjector potentially would improve QoL. \\
\hline & \multirow{2}{*}{$\begin{array}{l}\text { Limmroth \& } \\
\text { Gerbershagen } \\
2014^{43}\end{array}$} & \multirow{2}{*}{$\begin{array}{l}\text { Expert } \\
\text { opinion }\end{array}$} & - Authors focus on single-use autoinjector for once-weekly intramuscular delivery. \\
\hline & & & $\begin{array}{l}\text { - Authors described a preference for the devices and suggested that they might } \\
\text { contribute to improve adherence and QoL. }\end{array}$ \\
\hline & \multirow[t]{5}{*}{$\begin{array}{l}\text { Wray et al, } \\
2018^{48}\end{array}$} & \multirow[t]{5}{*}{$\begin{array}{l}\text { Research } \\
\text { article }\end{array}$} & $\begin{array}{l}\text { - REDEFINE clinical trial (phase IV, randomized, multicenter, two-center, crossover } \\
\text { study), } N=97 \text { relapsing-remitting multiple sclerosis patients. }\end{array}$ \\
\hline & & & $\begin{array}{l}\text { - Assessments: patient perceptions (ease-of-use, satisfaction and QoL), compliance and } \\
\text { safety. }\end{array}$ \\
\hline & & & - Comparison of single-use autoinjector vs reusable autoinjector. \\
\hline & & & - Results: both devices were perceived as easy or very easy to use. \\
\hline & & & $\begin{array}{l}\text { - Authors speculate having two autoinjector options may offer the potential to } \\
\text { accommodate patient preferences. }\end{array}$ \\
\hline \multirow{4}{*}{$\begin{array}{l}\text { - No drug } \\
\text { - Healthy } \\
\text { individuals }\end{array}$} & \multirow{4}{*}{$\begin{array}{l}\text { Berteau et al, } \\
2010^{44}\end{array}$} & \multirow{4}{*}{$\begin{array}{l}\text { Research } \\
\text { article }\end{array}$} & - Randomized, single-center, crossover study, $\mathrm{N}=40$ healthy volunteers. \\
\hline & & & $\begin{array}{l}\text { - Assessments: device performance, patient perceptions (preference and acceptance), } \\
\text { compliance, safety. }\end{array}$ \\
\hline & & & - Comparison of self-injections by a pen vs syringe by healthcare personnel. \\
\hline & & & $\begin{array}{l}\text { - Results: although both methods performed almost equally, patients prefer and has } \\
\text { greater acceptance for autoinjector. }\end{array}$ \\
\hline \multirow[t]{4}{*}{$\begin{array}{l}\text { - No drug } \\
\text { - Rheumatoid } \\
\text { arthritis }\end{array}$} & \multirow[t]{4}{*}{$\begin{array}{l}\text { Schwarzenbach } \\
\text { et al, } 2014^{47}\end{array}$} & \multirow[t]{4}{*}{$\begin{array}{l}\text { Research } \\
\text { article }\end{array}$} & $\begin{array}{l}\text { - Randomized, single-center, crossover study, } \mathrm{N}=65 \mathrm{RA} \text { patients. } \\
\text { - Assessments: patient perceptions (ease/comfort of use, acceptance), usability and } \\
\text { compliance. }\end{array}$ \\
\hline & & & $\begin{array}{l}\text { - Evaluation of an autoinjector regardless the treatment by performing mock injections } \\
\text { finding a high level of patient acceptance. }\end{array}$ \\
\hline & & & - Results: high acceptance and compliance. \\
\hline & & & $\begin{array}{l}\text { - Authors speculate use of autoinjector may improve compliance of patients with chronic } \\
\text { diseases. }\end{array}$ \\
\hline
\end{tabular}

(Continued) 
Table I (Continued).

\begin{tabular}{|c|c|c|c|}
\hline $\begin{array}{l}\text { Drug Delivered } \\
\text { and Condition }\end{array}$ & Reference & $\begin{array}{l}\text { Type of } \\
\text { Publication }\end{array}$ & Summary \\
\hline \multirow{15}{*}{$\begin{array}{l}\text { - DMARD- } \\
\text { biologics } \\
\text { - Rheumatoid } \\
\text { arthritis }\end{array}$} & \multirow{3}{*}{$\begin{array}{l}\text { Thakur et al, } \\
2016^{50}\end{array}$} & \multirow{3}{*}{$\begin{array}{l}\text { Research } \\
\text { article }\end{array}$} & - Survey, N = 220 patients. \\
\hline & & & $\begin{array}{l}\text { - Questionnaires to evaluate patient perceptions and preferences, ranking of attributes } \\
\text { patient most preferred. }\end{array}$ \\
\hline & & & - Comparison of two etanercept-charged autoinjectors. \\
\hline & \multirow[t]{4}{*}{$\begin{array}{l}\text { Schiff et al, } \\
2016^{51}\end{array}$} & \multirow[t]{4}{*}{$\begin{array}{l}\text { Research } \\
\text { article }\end{array}$} & $\begin{array}{l}\text { - Two simulated-use studies with no drug: formative with } N=54 \text { patients and summative } \\
\text { with } N=99 \text { patients. }\end{array}$ \\
\hline & & & $\begin{array}{l}\text { - Assessments: usability, acceptability and patient perceptions (comfort, control, ease of } \\
\text { use, confidence of dose). }\end{array}$ \\
\hline & & & - Evaluation of abatacept autoinjector. \\
\hline & & & $\begin{array}{l}\text { - Results: usability without error-patterns, high acceptability, preference over } \\
\text { competitors in those experienced patients. }\end{array}$ \\
\hline & \multirow[t]{4}{*}{$\begin{array}{l}\text { Schulze-Koops } \\
\text { et al, } 2015^{52}\end{array}$} & \multirow[t]{4}{*}{$\begin{array}{l}\text { Research } \\
\text { article }\end{array}$} & $\begin{array}{l}\text { - GO-MORE clinical trial [non-randomized (parallel assignment), open-label, } \\
\text { multinational], } N=3280 \text { patients. }\end{array}$ \\
\hline & & & - Efficacy outcomes. \\
\hline & & & $\begin{array}{l}\text { - Golimumab treatment: comparison of administered injections vs self-injections by an } \\
\text { injector. }\end{array}$ \\
\hline & & & - Results: patients self-injected less baseline disease activity. \\
\hline & \multirow[t]{4}{*}{$\begin{array}{l}\text { Kivitz et al, } \\
2018^{54}\end{array}$} & \multirow[t]{4}{*}{$\begin{array}{l}\text { Research } \\
\text { article }\end{array}$} & $\begin{array}{l}\text { - EASY clinical trial (randomized, open-label, multicenter, parallel-group), } N=217 \text { active- } \\
\text { to-severe RA patients. }\end{array}$ \\
\hline & & & $\begin{array}{l}\text { - Assessments: device robustness and usability, patient perceptions (diaries, survey) and } \\
\text { satisfaction, pharmacokinetics, safety and efficacy. }\end{array}$ \\
\hline & & & - Sarilumab: comparison of a single-use disposable pen vs prefilled syringes \\
\hline & & & - Patient were satisfied and confident with the pen and also found it easy to use. \\
\hline
\end{tabular}

Abbreviations: DM2, type 2 diabetes mellitus; MPR, medication possession ratio; QoL, quality of life; RA, rheumatoid arthritis.

the use of devices for self-injection have also been demonstrated with currently available devices for golimumab ${ }^{52}$ and sarilumab. ${ }^{54}$ These are encouraging results if we consider that a good perception and tolerance of self-administration is among the patient-related factors that influence medication adherence, which, in turn, is essential for long-term efficacy.

\section{Pen/Autoinjector Devices versus Prefilled Syringes in the Administration of MTX}

To address potential problems with injections such as patient grip and dexterity limitations, various injection technologies such as autoinjection devices have been introduced, which are designed to improve the ease of use, safety and reliability of injections, and to reduce pain. Also, frequently, patients associate SC injections with pain, discomfort, blood, and cross infection. ${ }^{55}$ Autoinjectors automatically insert the needle and deliver a controlled dose of drug, such as the diseasemodifying drugs used by patients with RA. Autoinjectors have been shown to provide a number of benefits, including a reduced risk of injection site reactions, reduced discomfort, and greater ease of use compared with manual (syringe plus needle) injections. ${ }^{47}$

Several studies have been performed to assess self-administration devices of MTX for RA and other immune-mediated inflammatory joint and skin diseases. MTX autoinjectors, for example, enable the $\mathrm{SC}$ administration without the need for opening a vial, handling a needle, or preparing and operating a syringe. 
In a Phase 2 clinical trial in patients with RA who had functional limitations, the MTX autoinjector was well tolerated and easy to use in the view of patients with RA and their functional limitations. ${ }^{53}$ The device was rated easy to use by $98 \%$, and instructions clear and easy to follow by $100 \%$ of patients. The authors concluded that improving SC methotrexate delivery may increase patient tolerance of self-administration, possibly improving adherence. $^{53}$

In a randomized crossover study comparing the pre-filled pen containing (MTX) Metex ${ }^{\circledR} /$ Metoject $^{\circledR}$ PEN with the reference MTX prefilled syringe in 120 patients requiring initiation or intensification of MTX therapy for RA, ${ }^{55} 76 \%$ of patients expressed their overall preference with the MTX pre-filled pen over the prefilled syringe after 6 weeks of treatment, as well as their preference in terms of use, acceptability and satisfaction with the pen. This positive perception of the prefilled-pen was further supported by the healthcare personnel involved in the study. Findings from other study designed to assess the usability, label comprehension, robustness, bioavailability, and safety of SC self-administration of MTX using the same MTX pen concluded that the pen was a viable delivery system attending to patient perceptions for patient candidates to SC MTX. ${ }^{56}$ The first attempt to use of MTX pen was successful, comfortable, and safe with all adverse events of mild intensity observed. ${ }^{56}$ Patients also indicated that MTX pen seemed even more convenient than oral MTX, and many of them were especially satisfied with the relative pain-free. These studies are summarized in Table 2.

\section{Discussion}

Treatment nonadherence is a major issue in contemporary medicine, particularly in chronic diseases, compromising the efficacy of a treatment. The development and implementation of medications delivered SC via autoinjector/pen devices and single-use syringes have become increasingly common for the treatment of chronic disorders such as RA. Newer injection technologies have been designed to improve the ease of use, reliability and safety as well as to minimize injection pain. Importantly, patients with RA and other chronic disorders have been found to prefer pen devices when compared to more conventional methods of treatment administration such as syringes in clinical trials. ${ }^{47,50-52,54,55}$

Strategies to be implemented in clinical practice for inquiring about patients' preferences have been described, ${ }^{1-3,9,11}$ and its integration in the decision-making process seems to be justified. In this regard, several reviews have confirmed that a wide range of interventions can improve medication adherence ${ }^{57}$ and that patients with several chronic disorders entered into support programs to assist them with nurse support, medication reminders, injection training, and pen disposal reported greater adherence and persistence, and lower total costs. ${ }^{58}$ The reduction of total healthcare costs due to improved adherence was demonstrated in patients with DM2 who used insulin pens. ${ }^{59}$

The importance of SC MTX in the management of RA is clear given its favorable bioavailability and pharmacodynamic profile over oral delivery. ${ }^{16-20,22,27}$ Consequently, the potential benefits in clinical outcomes need to be explored with more real-world data and cost-effectiveness studies to support its use as part of the management of patients with RA. In fact, in patients with RA intolerant or with an inadequate response to oral MTX, the switch to SC MTX has demonstrated to improve disease control and delay the time of beginning a biological agent. ${ }^{56}$ However, patients with RA may have difficulty in manipulating and self-administering SC MTX syringes and other SC therapies. Also, many patients associate $\mathrm{SC}$ administration with pain and discomfort, which, in turn, leads to less motivated patients and less likely to be adherent. Therefore, attempts to address potential problems with injections such as autoinjection devices with automatically insert the needle and deliver a controlled dose of drug have been introduced.

Pen devices seem to meet the expectations of the patients, not only in RA but in a wide number of chronic disorders and current evidence shows that they are preferred over conventional methods of treatment administration. The high level of usability and satisfaction with MTX pre-filled pens, regardless of the level of dexterity, is also supported by the perceptions of the healthcare personnel. Our search strategy demonstrated that there are no specific studies in RA that directly addressed the relationship between the use of autoinjector pens and treatment adherence, so we encourage the scientific community to further explore this issue. The current evidence assessing the usability, tolerability and convenience of distinct systems of SC MTX delivery have not directly evaluated the potential benefits in patient's adherence. However, data from other chronic diseases pointed out that optimized drug-administration systems increase patient adherence and, probably, improve disease outcomes. Further studies are warranted to explore any area of improvement in the personal, professional and social performance of the patients with RA. 
Table 2 Reports Studying MTX Pen/Autoinjectors

\begin{tabular}{|c|c|c|c|c|}
\hline Reference & Summary & Device & Variables & Main Outcomes \\
\hline \multirow[t]{6}{*}{$\begin{array}{l}\text { Freundlich et al, } \\
2014^{53}\end{array}$} & \multirow{3}{*}{$\begin{array}{l}\text { Phase II clinical trial (NCT0I6I8955) to assess the } \\
\text { performance of an MTX autoinjector together with } \\
\text { the subject perceptions about it in RA patients with } \\
\text { physical limitations. }\end{array}$} & \multirow[t]{6}{*}{$\begin{array}{l}\text { OTREXUP } \\
\text { (methotrexate) }\end{array}$} & $\begin{array}{l}\text { - Device: reliability } \\
\text { and robustness. }\end{array}$ & $\begin{array}{l}\text { - All devices correctly } \\
\text { functioned. }\end{array}$ \\
\hline & & & \multirow{5}{*}{$\begin{array}{l}\text { Patient safety, } \\
\text { local tolerance, } \\
\text { and ease of use. }\end{array}$} & $\begin{array}{l}\text { - } 98 \% \text { agreed or strongly } \\
\text { agreed device is easy to use. }\end{array}$ \\
\hline & & & & $\begin{array}{l}\text { - All patients agreed that the } \\
\text { instructions and training were } \\
\text { easy to follow. }\end{array}$ \\
\hline & \multirow[t]{3}{*}{$\mathrm{N}=10 \mathrm{I}$ patients. } & & & $\begin{array}{l}\text { - Patient experienced } \\
\text { minimal site-injection pain } \\
\text { (VAS scores were minimal). }\end{array}$ \\
\hline & & & & $\begin{array}{l}-\approx 92 \% \text { of patients noted no } \\
\text { erythema. }\end{array}$ \\
\hline & & & & $\begin{array}{l}\text { - There were no adverse } \\
\text { events related to the study. }\end{array}$ \\
\hline \multirow[t]{6}{*}{$\begin{array}{l}\text { Demary et al, } \\
2014^{55}\end{array}$} & \multirow[t]{3}{*}{$\begin{array}{l}\text { Phase III clinical trial (NCTOI793259) to compare } \\
\text { (through crossover design) subject perceptions } \\
\text { about two formats of analogous devices, prefilled } \\
\text { syringe versus prefilled pens, in RA patients. }\end{array}$} & \multirow[t]{6}{*}{$\begin{array}{l}\text { (methotrexate) } \\
\text { PEN }\end{array}$} & - Preference. & $\begin{array}{l}\text { - } 75 \% \text { of patients and } 92 \% \text { of } \\
\text { nurses and investigators } \\
\text { preferred the pen over the } \\
\text { syringe. }\end{array}$ \\
\hline & & & - Ease of use. & $\begin{array}{l}\text { - } 73-76 \% \text { of patients } \\
\text { preferred the pen in relation } \\
\text { to use, acceptability and } \\
\text { satisfaction. }\end{array}$ \\
\hline & & & - Acceptability. & $\begin{array}{l}\text { - Differences in local } \\
\text { tolerability between both } \\
\text { devices were found for pain } \\
\text { and redness. }\end{array}$ \\
\hline & \multirow[t]{3}{*}{$\mathrm{N}=120$ patients. } & & - Satisfaction. & \multirow{3}{*}{$\begin{array}{l}-\approx 32 \% \text { of patients suffered } \\
\text { adverse events, being the } \\
\text { most frequent infections and } \\
\text { infestations. }\end{array}$} \\
\hline & & & - Local tolerability. & \\
\hline & & & - Safety & \\
\hline \multirow[t]{4}{*}{$\begin{array}{l}\text { Pachon et al, } \\
2014^{56}\end{array}$} & \multirow[t]{2}{*}{$\begin{array}{l}\text { Clinical trial (NCTOI87I96I) to assess the } \\
\text { performance of an MTX autoinjector together with } \\
\text { the subject perceptions about it in RA patients. }\end{array}$} & \multirow[t]{4}{*}{$\begin{array}{l}\text { (methotrexate) } \\
\text { PEN }\end{array}$} & $\begin{array}{l}\text { - Patient } \\
\text { perception of } \\
\text { usability and label } \\
\text { comprehension. }\end{array}$ & $\begin{array}{l}\text { - Between } 90 \text { and } 100 \% \text { of } \\
\text { the patients found "very easy" } \\
\text { tasks proposed in } 4 \text { scenarios. }\end{array}$ \\
\hline & & & $\begin{array}{l}\text { - Device } \\
\text { robustness. }\end{array}$ & $\begin{array}{l}-\approx 98 \% \text { of patients scored } \\
80 \% \text { in the written exam after } \\
\text { the training. }\end{array}$ \\
\hline & \multirow[t]{2}{*}{$\mathrm{N}=105$ patients. } & & \multirow[t]{2}{*}{$\begin{array}{l}\bullet \\
\text { Pharmacokinetics. }\end{array}$} & $\begin{array}{l}-\approx 98 \% \text { of patients scored } \\
80 \% \text { in the written exam after } \\
\text { the training. }\end{array}$ \\
\hline & & & & $\begin{array}{l}\text { - Within all the pens } \\
\text { employed, one had liquid leak } \\
\text { and another had a bent } \\
\text { needle. }\end{array}$ \\
\hline
\end{tabular}

Abbreviations: MTX, methotrexate; RA, rheumatoid arthritis; VAS, visual analogue scale. 
A potential limitation of this review could be that it does not explore the benefits of self-administration systems for pediatric patients despite the undeniable influence of treatment adherence in this population too. We aimed to review how the use of MTX self-injection devices can improve treatment experience, but since there is a lack of evidence on the benefits of MTX selfinjection devices in children, we did not explore jointly adult and pediatric population. However, given the barriers to the administration of parenteral formulations in children and young people we consider that all the main conclusions presented here could be extrapolated from the review population to pediatric setting. Studies specifically driven to understand the factors influencing children and parent/carer attitudes to treatment adherence are required to reinforce these conclusions and align the design of administration devices for pediatric use more to patient needs.

In children and adolescents, MTX also constitutes the mainstay treatment for many of the chronic inflammatory diseases, given its demonstrated effectiveness both in oral and SC formulations. The most common use in pediatric population corresponds to juvenile idiopathic arthritis (JIA), especially polyarticular and oligoarticular and uveitis associated or not with JIA. ${ }^{60-68}$ Until recently, oral tablets have been the preferred form of administration in pediatric patients, reserving $\mathrm{SC}$ administration for those requiring weekly doses of at least $15 \mathrm{mg} / \mathrm{m}^{2}$ or have intolerance or psychological aversion. ${ }^{63,69}$ In routine practice, it is usual to intensify the treatment with MTX by switching to the SC route before starting biologic agents. As in adults, adherence evaluation is not standardized in pediatrics although it is assumed as the number of missed doses of those prescribed for a specified period of time. Factors of poor adherence and persistence to MTX would be assumed similar in pediatrics and adults keeping in mind the following features:

- Patient's age: in children, adherence mainly depends on the attitude of parents or carers. However, noncompliance in adolescents is probably more frequent due to the inherent characteristics of this age of a need for independence and self-affirmation. The use of self-injectable devices in adolescents would favor adherence to methotrexate as this form of administration reduces parental guidance or healthcare personnel supervision. The procedure of self- injection would therefore help the patients maintain independence and promote their maturity.

- Abilities of patients for using injectables. Patients with RA and to lesser extent children with JIA may be limited in their ability to self-administer conventional injectables due to the involvement of hand joints. The easier and faster procedure of using selfinjectable devices would favor the administration of SC methotrexate in this group of patients.

- Side effects and patient tolerance: many children develop psychological aversion to methotrexate including anticipatory nausea or behavioral distress before its administration. In such cases, switching from oral to $\mathrm{SC}$ administration anticipates possible improved adherence.

- Fear of needles and pain associated with the injection that is so traumatic for children could be reduced with self-injection. Also, the lower incidence of site skin reactions observed with the use of auto-injectors compared with syringes may reduce the significant impact they have on patient compliance with chronic injectable treatments, especially in pediatric population where local skin reactions may trigger discomfort and phobias. Even the lower required training to self-injecting medication compared to syringes is key to improve adherence and reduce the visits to healthcare centers while saving costs.

\section{Conclusion}

Patients with RA intolerant or with an inadequate response to oral MTX have demonstrated to improve disease control as a result of switching to SC MTX. Even though patients with RA may have difficulty in manipulating and selfadministering SC MTX syringes and other SC therapies, the introduction of autoinjection devices, which allows automatically insert the needle and deliver a controlled dose of drug, has demonstrated that self-injection versus injection by health care workers may increase treatment adherence and, consequently, reduce costs by decreasing the frequency of hospital visits.

Overall, data reported here highlight the value of the autoinjection in patients with RA as a means to adapt their treatment to specific needs, improve the injection experience by mitigating the fear and anxiety, overcome the challenges resulting from hand dexterity problems, and empower them to take control of their treatment journey. By optimizing SC delivery of therapies, preference and satisfaction will improve, potentially improving adherence 
and treatment outcomes. This is especially important in chronic diseases where proper therapeutic adherence may be as efficient as any medical progress.

\section{Abbreviations}

ACR/ARHP, American College of Rheumatology's annual meeting; AUC, area under the curve; CQR, compliance questionnaire rheumatology; DMARDs, diseasemodifying antirheumatic drugs; DM2, type 2 diabetes mellitus; EULAR, European League Against Rheumatism; JIA, juvenile idiopathic arthritis; QoL, quality of life; MARS-5, medication adherence report scale; MEMS, medication event monitoring system; MESH, medical subject headings; MPR, medication possession ratio; MTX, methotrexate; RA, rheumatoid arthritis; SC, Subcutaneous; VAS, visual analogue scale; WHO, World Health Organization.

\section{Author Contributions}

All authors have substantially (i) contributed to the acquisition, analysis or interpretation of data, (ii) drafted the manuscript and critically revised the manuscript for important intellectual content, (iii) have agreed on the journal which the article will be submitted, (iv) gave final approval of the version to be published, and (v) agreed to take responsibility and be accountable for the contents of the article.

\section{Funding}

This Project was funded by Laboratorios Gebro Pharma S.A.

\section{Disclosure}

J.T.M has received honoraria from Gebro Pharma and Sanofi. J.C.L.R has received honoraria from Gebro Pharma. N.C.R is an employee of Gebro Pharma, Spain. The authors report no other conflicts of interest in this work.

\section{References}

1. Iuga AO, McGuire MJ. Adherence and health care costs. Risk Manag Healthc Policy. 2014;7:35-44. doi:10.2147/RMHP.S19801

2. Osterberg L, Blaschke T. Adherence to medication. $N$ Engl $J$ Med. 2005;353(5):487-497. doi:10.1056/NEJMra050100

3. World Health Organization. Adherence to long-term therapies: evidence for action. WHO adherence report; 2003. Available from: https://www.who.int/chp/knowledge/publications/adherence_full_ report.pdf?ua=1. Accessed March 5, 2021.

4. Brown MT, Bussell JK. Medication adherence: WHO cares? Mayo Clin Proc. 2011;86(4):304-314. doi:10.4065/mcp.2010.0575
5. Scott DL, Wolfe F, Huizinga TW. Rheumatoid arthritis. Lancet. 2010;376(9746):1094-1108. doi:10.1016/S0140-6736(10)60826-4

6. Humphreys JH, Verstappen SM, Hyrich KL, Chipping J, Symmons DP. 2010 ACR/EULAR classification criteria for rheumatoid arthritis predict increased mortality in patients with early arthritis: results from the Norfolk Arthritis Register. Rheumatology (Oxford). 2013;52(6):1141-1142. doi:10.1093/rheumatology/ket113

7. Kapetanovic MC, Lindqvist E, Nilsson JA, Geborek P, Saxne T, Eberhardt K. Development of functional impairment and disability in rheumatoid arthritis patients followed for 20 years: relation to disease activity, joint damage, and comorbidity. Arthritis Care Res. 2015;67(3):340-348. doi:10.1002/acr.22458

8. Elliott RA, Shinogle JA, Peele P, Bhosle M, Hughes DA. Understanding medication compliance and persistence from an economics perspective. Value Health. 2008;11(4):600-610. doi:10.1111/ j.1524-4733.2007.00304.x

9. van der Weijden T, Legare F, Boivin A, et al. How to integrate individual patient values and preferences in clinical practice guidelines? A research protocol. Implement Sci. 2010;5(1):10. doi:10.1186/1748-5908-5-10

10. Shingler SL, Bennett BM, Cramer JA, Towse A, Twelves C, Lloyd AJ. Treatment preference, adherence and outcomes in patients with cancer: literature review and development of a theoretical model. Curr Med Res Opin. 2014;30(11):2329-2341. doi:10.1185/ 03007995.2014.952715

11. (UK) NCCfPCU-RCoGP. Medicines Adherence: Involving Patients in Decisions About Prescribed Medicines and Supporting Adherence: NICE Clinical Guidelines. Vol. 76. 2009.

12. Curtis JR, Bykerk VP, Aassi M, Schiff M. Adherence and persistence with methotrexate in rheumatoid arthritis: a systematic review. J Rheumatol. 2016;43(11):1997-2009. doi:10.3899/jrheum.151212

13. De Cuyper E, De Gucht V, Maes S, Van Camp Y, De Clerck LS. Determinants of methotrexate adherence in rheumatoid arthritis patients. Clin Rheumatol. 2016;35(5):1335-1339. doi:10.1007/ s10067-016-3182-4

14. Fautrel B, Balsa A, Van Riel P, et al. Influence of route of administration/drug formulation and other factors on adherence to treatment in rheumatoid arthritis (pain related) and dyslipidemia (non-pain related). Curr Med Res Opin. 2017;33(7):1231-1246. doi:10.1080/ 03007995.2017.1313209

15. Muller S, Wilke T, Fuchs A, et al. Non-persistence and non-adherence to MTX therapy in patients with rheumatoid arthritis: a retrospective cohort study based on German RA patients. Patient Prefer Adherence. 2017;11:1253-1264. doi:10.2147/PPA.S134924

16. Tornero Molina J, Calvo Alen J, Ballina J, et al. Recommendations for the use of parenteral methotrexate in rheumatic diseases. Reumatol Clin. 2018;14(3):142-149. doi:10.1016/j.reuma.2016.12.001

17. Tornero Molina J, Ballina Garcia FJ, Calvo Alen J, et al. Recommendations for the use of methotrexate in rheumatoid arthritis: up and down scaling of the dose and administration routes. Reumatol Clin. 2015;11(1):3-8. doi:10.1016/j.reuma.2014.02.012

18. Rohr MK, Mikuls TR, Cohen SB, Thorne JC, O'Dell JR. Underuse of methotrexate in the treatment of rheumatoid arthritis: a national analysis of prescribing practices in the US. Arthritis Care Res. 2017;69 (6):794-800. doi:10.1002/acr.23152

19. Koduri GM, Mukhtyar C. Why subcutaneous methotrexate should be a prerequisite to biologic use in patients with rheumatoid arthritis. Rheumatology (Oxford). 2018.

20. Braun J, Kastner P, Flaxenberg P, et al. Comparison of the clinical efficacy and safety of subcutaneous versus oral administration of methotrexate in patients with active rheumatoid arthritis: results of a six-month, multicenter, randomized, double-blind, controlled, Phase IV trial. Arthritis Rheum. 2008;58(1):73-81. doi:10.1002/art.23144

21. Smolen JS, Landewe R, Bijlsma J, et al. EULAR recommendations for the management of rheumatoid arthritis with synthetic and biological disease-modifying antirheumatic drugs: 2016 update. Ann Rheum Dis. 2017;76(6):960-977. doi:10.1136/annrheumdis-2016-210715 
22. Ridyard CH, Dawoud DM, Tuersley LV, Hughes DA. A systematic review of patients' perspectives on the subcutaneous route of medication administration. Patient. 2016;9(4):281-292. doi:10.1007/ s40271-015-0160-x

23. Sackett DRW, Rosenburg W, Haynes RB. How to Practice and Teach Evidence Based Medicine. 2nd ed. Churchill Livingstone; 1997.

24. Cramer JA, Roy A, Burrell A, et al. Medication compliance and persistence: terminology and definitions. Value Health. 2008;11 (1):44-47. doi:10.1111/j.1524-4733.2007.00213.x

25. Tiktin M, Celik S, Berard L. Understanding adherence to medications in type 2 diabetes care and clinical trials to overcome barriers: a narrative review. Curr Med Res Opin. 2016;32(2):277-287. doi:10.1185/03007995.2015.1119677

26. Hazlewood GS, Thorne JC, Pope JE, et al. The comparative effectiveness of oral versus subcutaneous methotrexate for the treatment of early rheumatoid arthritis. Ann Rheum Dis. 2016;75(6):1003-1008. doi:10.1136/annrheumdis-2014-206504

27. Tornero Molina J. Clinical utility of parenteral methotrexate administration in patients with rheumatic diseases. Reumatol Clin. 2016;11(1):16-21.

28. Islam MS, Haq SA, Islam MN, et al. Comparative efficacy of subcutaneous versus oral methotrexate in active rheumatoid arthritis. Mymensingh Med J. 2013;22(3):483-488.

29. Dhaon P, Das SK, Srivastava R, Agarwal G, Asthana A. Oral methotrexate in split dose weekly versus oral or parenteral methotrexate once weekly in rheumatoid arthritis: a short-term study. Int $J$ Rheum Dis. 2018;21(5):1010-1017. doi:10.1111/1756-185X.12910

30. Bello AE, Perkins EL, Jay R, Efthimiou P. Recommendations for optimizing methotrexate treatment for patients with rheumatoid arthritis. Open Access Rheumatol. 2017;9:67-79. doi:10.2147/ OARRR.S131668

31. Tornero-Molina J, Andreu JL, Martin-Martinez MA, et al. Methotrexate in patients with rheumatoid arthritis in Spain: subanalysis of the AR excellence project. Reumatol Clin. 2017.

32. Vena GA, Cassano N, Iannone F. Update on subcutaneous methotrexate for inflammatory arthritis and psoriasis. Ther Clin Risk Manag. 2018;14:105-116. doi:10.2147/TCRM.S154745

33. Scott DG, Claydon P, Ellis C. Retrospective evaluation of continuation rates following a switch to subcutaneous methotrexate in rheumatoid arthritis patients failing to respond to or tolerate oral methotrexate: the MENTOR study. Scand J Rheumatol. 2014;43 (6):470-476. doi:10.3109/03009742.2014.910312

34. Fitzpatrick R, Scott DG, Keary I. Cost-minimisation analysis of subcutaneous methotrexate versus biologic therapy for the treatment of patients with rheumatoid arthritis who have had an insufficient response or intolerance to oral methotrexate. Clin Rheumatol. 2013;32(11):1605-1612. doi:10.1007/s10067-013-2318-z

35. Lee J, Pelkey R, Gubitosa J, Henrick MF, Ganz ML. Comparing healthcare costs associated with oral and subcutaneous methotrexate or biologic therapy for rheumatoid arthritis in the United States. Am Health Drug Benefits. 2017;10(1):42-49.

36. Taylor PC, Balsa Criado A, Mongey AB, Avouac J, Marotte H, Mueller RB. How to get the most from methotrexate (MTX) treatment for your rheumatoid arthritis patient?-MTX in the treat-to-target strategy. J Clin Med. 2019;8(4). doi:10.3390/jcm8040515

37. Cheen HH, Lim SH, Huang MC, Bee YM, Wee HL. Adherence to premixed insulin in a prefilled pen compared with a vial/syringe in people with diabetes in Singapore. Clin Ther. 2014;36(7):1043-1053. doi:10.1016/j.clinthera.2014.05.009

38. Miao R, Wei W, Lin J, Xie L, Baser O. Does device make any difference? A real-world retrospective study of insulin treatment among elderly patients with type 2 diabetes. $J$ Diabetes Sci Technol. 2014;8(1):150-158. doi:10.1177/1932296813516956

39. Ramadan WH, Khreis NA, Kabbara WK. Simplicity, safety, and acceptability of insulin pen use versus the conventional vial/syringe device in patients with type 1 and type 2 diabetes mellitus in Lebanon. Patient Prefer Adherence. 2015;9:517-528. doi:10.2147/PPA.S78225
40. Lasalvia P, Barahona-Correa JE, Romero-Alvernia DM, et al. Pen devices for insulin self-administration compared with needle and vial: systematic review of the literature and meta-analysis. J Diabetes Sci Technol. 2016;10(4):959-966. doi:10.1177/1932296816633721

41. Lopez A, Billioud V, Peyrin-Biroulet C, Peyrin-Biroulet L. Adherence to anti-TNF therapy in inflammatory bowel diseases: a systematic review. Inflamm Bowel Dis. 2013;19(7):1528-1533. doi:10.1097/MIB.0b013e31828132cb

42. Vermeire S, D'Heygere F, Nakad A, et al. Preference for a prefilled syringe or an auto-injection device for delivering golimumab in patients with moderate-to-severe ulcerative colitis: a randomized crossover study. Patient Prefer Adherence. 2018;12:1193-1202. doi:10.2147/PPA.S154181

43. Limmroth V, Gerbershagen K. Single-use autoinjector for once-weekly intramuscular injection of IFNbeta-1a. Expert Opin Drug Deliv. 2014;11 (12):1969-1978. doi:10.1517/17425247.2014.943181

44. Berteau C, Schwarzenbach F, Donazzolo Y, et al. Evaluation of performance, safety, subject acceptance, and compliance of a disposable autoinjector for subcutaneous injections in healthy volunteers. Patient Prefer Adherence. 2010;4:379-388. doi:10.2147/PPA.S13132

45. Arthur AB, Klinkhoff AV, Teufel A. Safety of self-injection of gold and methotrexate. J Rheumatol. 1999;26(2):302-305.

46. Keininger D, Coteur G. Assessment of self-injection experience in patients with rheumatoid arthritis: psychometric validation of the Self-Injection Assessment Questionnaire (SIAQ). Health Qual Life Outcomes. 2011;9:2. doi:10.1186/1477-7525-9-2

47. Schwarzenbach F, Dao Trong M, Grange L, et al. Results of a human factors experiment of the usability and patient acceptance of a new autoinjector in patients with rheumatoid arthritis. Patient Prefer Adherence. 2014;8:199-209. doi:10.2147/PPA.S50583

48. Wray S, Hayward B, Dangond F, Singer B. Ease of use of two autoinjectors in patients with multiple sclerosis treated with interferon beta-1a subcutaneously three times weekly: results of the randomized, crossover REDEFINE study. Expert Opin Drug Deliv. 2018;15(2):127-135. doi:10.1080/17425247.2018.1407755

49. Kivitz A, Cohen S, Dowd JE, et al. Clinical assessment of pain, tolerability, and preference of an autoinjection pen versus a prefilled syringe for patient self-administration of the fully human, monoclonal antibody adalimumab: the TOUCH trial. Clin Ther. 2006;28 (10):1619-1629. doi:10.1016/j.clinthera.2006.10.006

50. Thakur K, Biberger A, Handrich A, Rezk MF. Patient perceptions and preferences of two etanercept autoinjectors for rheumatoid arthritis: findings from a patient survey in Europe. Rheumatol Ther. 2016;3 (2):245-256. doi:10.1007/s40744-016-0048-9

51. Schiff M, Koo J, Jin E, et al. Usability and acceptability of the abatacept pre-filled autoinjector for the subcutaneous treatment of rheumatoid arthritis. Adv Ther. 2016;33(2):199-213. doi:10.1007/ s12325-016-0286-9

52. Schulze-Koops H, Giacomelli R, Samborski W, et al. Factors influencing the patient evaluation of injection experience with the SmartJect autoinjector in rheumatoid arthritis. Clin Exp Rheumatol. 2015;33 (2):201-208.

53. Freundlich B, Kivitz A, Jaffe JS. Nearly pain-free self-administration of subcutaneous methotrexate with an autoinjector: results of a phase 2 clinical trial in patients with rheumatoid arthritis who have functional limitations. J Clin Rheumatol. 2014;20(5):256-260. doi:10.1097/RHU.0000000000000117

54. Kivitz A, Baret-Cormel L, van Hoogstraten H, et al. Usability and patient preference phase 3 study of the sarilumab pen in patients with active moderate-to-severe rheumatoid arthritis. Rheumatol Ther. 2018;5(1):231-242. doi:10.1007/s40744-017-0090-2

55. Demary W, Schwenke H, Rockwitz K, et al. Subcutaneously administered methotrexate for rheumatoid arthritis, by prefilled syringes versus prefilled pens: patient preference and comparison of the self-injection experience. Patient Prefer Adherence. 2014;8:1061-1071. doi:10.2147/PPA.S64111 
56. Pachon JA, Kivitz AJ, Heuer KU, Pichlmeier U. Assessing usability, label comprehension, pen robustness and pharmacokinetics of a self-administered prefilled autoinjector pen of methotrexate in patients with rheumatoid arthritis. SAGE Open Med. 2014;2:2050312114564241. doi:10.1177/2050312114564241

57. Viswanathan M, Golin CE, Jones CD, et al. Interventions to improve adherence to self-administered medications for chronic diseases in the United States: a systematic review. Ann Intern Med. 2012;157 (11):785-795. doi:10.7326/0003-4819-157-11-201212040-00538

58. Rubin DT, Mittal M, Davis M, Johnson S, Chao J, Skup M. Impact of a patient support program on patient adherence to adalimumab and direct medical costs in Crohn's disease, ulcerative colitis, rheumatoid arthritis, psoriasis, psoriatic arthritis, and ankylosing spondylitis. J Manag Care Spec Pharm. 2017;23(8):859-867. doi:10.18553/ jmcp.2017.16272

59. Chandran A, Bonafede MK, Nigam S, Saltiel-Berzin R, Hirsch LJ, Lahue BJ. Adherence to insulin pen therapy is associated with reduction in healthcare costs among patients with type 2 diabetes mellitus. Am Health Drug Benefits. 2015;8(3):148-158.

60. Blazina S, Markelj G, Avramovic MZ, Toplak N, Avcin T. Management of juvenile idiopathic arthritis: a clinical guide. Paediatr Drugs. 2016;18 (6):397-412. doi:10.1007/s40272-016-0186-0

61. Calvo I, Anton J, Lopez Robledillo JC, et al. Recommendations for the use of methotrexate in patients with juvenile idiopathic arthritis. An Pediatr (Barc). 2016;84(3):177e171-178.

62. Cespedes-Cruz A, Gutierrez-Suarez R, Pistorio A, et al. Methotrexate improves the health-related quality of life of children with juvenile idiopathic arthritis. Ann Rheum Dis. 2008;67(3):309-314. doi:10.1136/ard.2007.075895

63. Franova J, Fingerhutova S, Kobrova K, et al. Methotrexate efficacy, but not its intolerance, is associated with the dose and route of administration. Pediatr Rheumatol Online J. 2016;14(1):36. doi:10.1186/s12969-016-0099-z

64. Giannini EH, Brewer EJ, Kuzmina N, et al. Methotrexate in resistant juvenile rheumatoid arthritis. Results of the U.S.A.-U.S.S.R. doubleblind, placebo-controlled trial. The Pediatric Rheumatology Collaborative Study Group and the Cooperative Children's Study Group. $N$ Engl J Med. 1992;326(16):1043-1049. doi:10.1056/ NEJM199204163261602
65. Klein A, Kaul I, Foeldvari I, Ganser G, Urban A, Horneff G. Efficacy and safety of oral and parenteral methotrexate therapy in children with juvenile idiopathic arthritis: an observational study with patients from the German Methotrexate Registry. Arthritis Care Res. 2012;64 (9):1349-1356. doi:10.1002/acr.21697

66. Niehues T, Lankisch P. Recommendations for the use of methotrexate in juvenile idiopathic arthritis. Paediatr Drugs. 2006;8(6):347-356. doi:10.2165/00148581-200608060-00003

67. Silverman E, Mouy R, Spiegel L, et al. Leflunomide or methotrexate for juvenile rheumatoid arthritis. $N$ Engl $J$ Med. 2005;352 (16):1655-1666. doi:10.1056/NEJMoa041810

68. Woo P, Southwood TR, Prieur AM, et al. Randomized, placebo-controlled, crossover trial of low-dose oral methotrexate in children with extended oligoarticular or systemic arthritis. Arthritis Rheum. 2000;43(8):1849-1857. doi:10.1002/1529-0131(200008) 43:8<1849::AID-ANR22>3.0.CO;2-F

69. Tukova J, Chladek J, Nemcova D, Chladkova J, Dolezalova P. Methotrexate bioavailability after oral and subcutaneous administration in children with juvenile idiopathic arthritis. Clin Exp Rheumatol. 2009;27(6):1047-1053.

70. Kivitz A, Segurado OG. HUMIRA pen: a novel autoinjection device for subcutaneous injection of the fully human monoclonal antibody adalimumab. Expert Rev Med Devices. 2007;4(2):109-116. doi:10.1586/17434440.4.2.109

71. Seddighzadeh A, Hung S, Selmaj K, et al. Single-use autoinjector for peginterferon-betala treatment of relapsing-remitting multiple sclerosis: safety, tolerability and patient evaluation data from the Phase IIIb ATTAIN study. Expert Opin Drug Deliv. 2014;11(11):1713-1720. doi:10.1517/17425247.2014.944159
Drug, Healthcare and Patient Safety

\section{Publish your work in this journal}

Drug, Healthcare and Patient Safety is an international, peer-reviewed open-access journal exploring patient safety issues in the healthcare continuum from diagnostic and screening interventions through to treatment, drug therapy and surgery. The journal is characterized by the rapid reporting of reviews, original research, clinical, epidemiological and post-marketing surveillance studies, risk management, health

\section{Dovepress}

literacy and educational programs across all areas of healthcare delivery. The manuscript management system is completely online and includes a very quick and fair peer-review system. Visit http://www.dovepress.com/testimonials.php to read real quotes from published authors. 